\title{
THE PLACE AND IMPORTANCE OF MUSIC IN EDUCATION: THE CASE OF HELLEN SOCIETY
}

\author{
Serkan ÇELİK ${ }^{1}$, Mehmet Yavuz ÇETINKAYA ${ }^{2}$
}

\begin{abstract}
The art of music stimulated the power of idea and imagery gradually in the stream of history, and found a unique style in every culture during every age and a way of expression which arose from the needs of that society. Although audio samples of Hellen music did not reach to medieval times, the idea and theory of Hellen music left many deep traces on western culture for centuries. During this period of time, the development of theater and lyrical poetry contributed to the development of music types and musical instruments significantly. In Hellen society, music was regarded as one of the types of art and science. In spite of the fact that there was a possibility for music to be used for the purposes such as; having rest, recreation and entertainment, it played significant and central role on daily and religious lives. Music had a large usage area and was used in nearly all the activities that constituted Hellen society. Particularly; religious ceremonies and theatrical performances in schools etc. In this context, various sources of information related to music were used in different literary and philosophical works. One of the most important reasons why music was quite significant in Hellen society arose from the importance given to music education. This research investigates the place and importance of music education in Hellen society. Teaching music in a right and proper way and providing education of one of the types of musical instrument while teaching prove that the art of music in education was highly regarded and taken seriously.
\end{abstract}

Keywords: Hellen; Music; Antique; Education; Society.

\footnotetext{
${ }^{1}$ Yrd.Doç.Dr. İzmir Kâtip Çelebi Üniversitesi, Turizm Fakültesi, Rekreasyon Yönetimi Bölümü, İzmir, scelik55(at)gmail.com

${ }^{2}$ Araştırma Görevlisi, İzmir Kâtip Çelebi Üniversitesi, Turizm Fakültesi, Turizm Rehberliği Bölümü, İzmir, myavuzcetinkaya(at)gmail.com
} 


\title{
HELLEN TOPLUMUNDA: MÜZiĞîN EĞiTiMDEKi YERI VE ÖNEMI
}

\begin{abstract}
ÖZET
Müzik sanatı, tarihin akışı içinde giderek düşünce ve imge gücünü uyarmış, her çağda, her kültürde kendine özgü bir üslup, o toplumun gereksiniminden doğan bir anlatım yolu bulmuştur. Hellen müziğinin ses örnekleri ortaçağa taşınmamış olsa da Hellen müzik düşüncesi ve kuramı, Batı kültüründe yüzyıllar boyu derin izler bırakmıştır. Bu dönemde tiyatronun ve lirik şiirin gelişmesi, şenlikler ve dansın önem kazanması müzik biçimleri ve çalgılarının gelişmesine yol açmıştır. Hellen toplumunda müzik sanattı aynı zamanda bilimdi. Dinlenme ve eğlence için kullanılabilecek olmasına rağmen günlük ve dini hayatlarında merkezi çok önemli bir rol üstleniyordu. Müzik Hellen yaşamındaki bütün faaliyetlerde kullanılmaktaydı: Özellikle okullarda, dini ayin, tiyatral performanslarında, dinlenme v.s.. Bu nedenden dolayı müzikle ilgili çeşitli bilgiler farklı edebi ve felsefik eserlerde görülebiliniyordu. Hellen toplumunda müziğin bu kadar önemli olmasını nedenlerinden en önemlisi, müzik eğitimine verilen ayrı bir önemden kaynaklanmaktadır. Bu yazıda Hellen toplumunda müziğin eğitimdeki yerinden bahsedilmektedir. Müziğin doğru öğretilmesi ve müziği öğretirken mutlaka yanında bir antik çalgının eğitiminin verilmesi müzik sanatının ne kadar ciddiye alındığının kanıtıdır.
\end{abstract}

Anahtar Kelimeler: Hellen; Müzik; Antik; Eğitim; Toplum. 


\section{Introduction}

The word "Mousike" is claimed to stem from Moses who is accepted as muse of music and all intellectual and artistic activities at the same time (Şahin 2013:121). Moreover, it has another meaning such as; an art belonging to Christ and worthy to Moses. " These are nine girls with co-hearted and all they need to do is to sign some melodies. These are nine divine daughters of great Zeus; Klio, Euterpe, Thalia, Melpomene, Terpsikhore, Erato, Polhymnia, Urania and Kalliope who is regarded as head of all. This is the thing that was given by Moses, all poets and musicians come from Moses and Archer Apollo on the earth, like the lings coming from Zeus (Erhat:1972). In this context, music is accepted as the most important symbol of music culture and education in Hellen society. The word "Mousikos Aner" was the word given as a name to the person with a high level of cultural background (Şahin 2013:121).

Music occupied a very significant place in education. The children who needed to be educated/trained in accordance with the doctrine of Plato were the ones who were superior to others inherently. These were the children who belong to "Protectors" class (the most important class in the society). Plato stated the equality of men and women by suggesting that all of these privileged children were to undergo the same education process (physical education, music, horse riding, using weapon etc.) regardless of their gender (Platon, La Republique, IV:409). The music education which was started from young ages was conducted by Paidagogos. In many examples, it was seen that the Lyra instructor was sitting with Lyra on his lap, probably singing and his student playing Aulos by sitting in front of him visually. There was no music stand as music education was performed through ear (Lenkins, 1989:18). The Lyra instructor maintained his students to control themselves and behave well in society via education. Later, the instructor thought students the songs, rhythm melodies, who learned how to play Lyra, harmless poets (changes according to period like today) (Pic.1). This education provided students with compliance to give some speech in larger organizations and behave well in the society (Levi, 1987:154).

According to ancient resources, music education consisted of three chapters; 1-Mod (Harmony Knowledge), 2-Rhythmic (Procedural Knowledge) and 3-Metric (Measure).Gevaert stated that harmony was a musical element and measurement was a poetical element and rhythm combined them. As a result of the combination of these different elements as a whole, the excellent melody/tune (composition) was born (i.e. music for human voice) (Gevaert, 1881:129). 


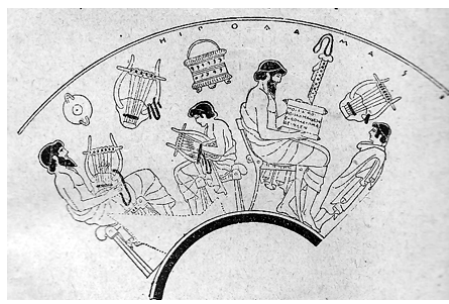

Picture 1: Children in school.

\section{Place and Importance of Music in Education}

On one hand, students would go to Palestra for sport lessons in the morning and on the other hand, they would go to Didaskaleion (School) for literature and music lessons in the afternoon. Although there is not so much information about the decorations of Didaskaleion walls, it is known that there is Moses, depictions of Dionysos masks and Dionysiak scenes on the walls. Moreover, it is known that Lyric poet Sappho owned a Didaskaleion, where girls were educated on behalf of her. Sappho has been a symbol of culture and literature from his time till today (Tenth Moses). The education system here aimed to train young girls as a gentlewoman/lady. Sappho was known to have played Lyra and especially Barbiton and was shown as the finder/inventor of Plektra (Pena).

Sappho's education was predominantly interested in music and choir. Girls would play Lyra and Barbiton. Plato defended an opinion that music education should be determined and regulated by law and as Ionia and Lydia tunes of music should be removed from music education, recommended that Phrygia and Doric tunes of music should be added to music education (Platon, State, III). Furthermore, Aristoteles discussed the place of music in education and found similarities close to reality between rhythm and music. All in all Aristotle emphasized that music was active in creating mental strength and should be in education. By examining the impact of all tunes of music on human being, he stated that Myksolydia tune providing sadness, Phrygia tune providing enthusiasm and Doric tune providing balance between these two tunes (Aristotle, Poetics, VIII). In addition to this, Aristotle pointed out that Lydia tune was suitable for childhood education (Paides). However, he was against to wind instruments in education. Among the stringed musical instruments which were not appropriate for playing, he accounted for Lydian Harp, seven stringed Lyra and Kithara. Aristotle thought that playing a musical instrument professionally and getting music education was not education (Aristotle, Poetics, VIII). However, the musical instrument Lyra which was used in schools was the seven stringed Lyra shown as an invention of Terpandros and 
opposed by Aristotle. The skill of playing Lyra was common among the aristocrats of archaic period. Achilles and Alexandros (Paris) played Lyra in Iliad like the masters of Pindaros. Themistocles was despised for not playing Lyra and singing (West, 1992:26). Even though Kimon could sign quite sufficient, it was stated that he lacked sufficient music education by a rival author. The expression "No ability in playing Lyra" in 420 B.C. had a meaning such as "No good educational background". Although Aristotele was in his old ages, he was getting Lyra lessons (Pic.2).

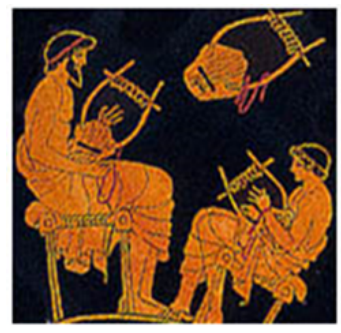

Picture 2: Lyra Lesson

The aim of Sappho's choral education/training was to educate young girls as gentlewoman/lady. In fact, this type of education/training was known to be valid for the entire Hellenic world. Moreover, Plato emphasized the importance of choir in education by stating that if a place had no Akhoreutos (No Choir), there was Apaidetus (Illiteracy). The first choir was the Moses and their number changed between 7 and 9 in the history. In Hellenic music world, adult males, females and children could be a choir member. Although there are examples of people with different genders dancing together in early period, there are no examples of people with different genders singing together (Webster, 1970:8-46). Adult men and children were singing separately. However, it is known that adult men and adult male children were singing together with a difference of one octave. In many cultures, it is accepted as a common method to sing with different voices in a parallel way. The parallelism of octave was only existent in Greek resources and the existence of others was denied (Sachs, 1962:81-177) (Pic.3). 


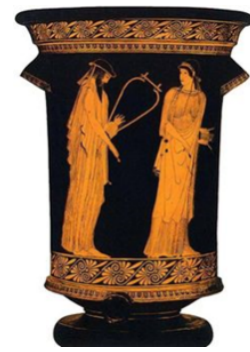

Picture 3: Athenian depiction of Sappho and Alcaeus, about 450 B.C.E.

According to an inscription in Teos, choir vocals among the female students having signing lessons were known to singing hymns in national and religious ceremonies led by Paidonomos (Dittenberger,1982:234).Choir was led by Khorodidaskalos (Choir Teacher/Instructor). Female students were known to having dance lessons as well as singing lessons in 2 nd century B.C. in Magnesia of Meander (Dittenberger, 1982:695). Plato, who was trying to protect some aspects of classical education in $4^{\text {th }}$ century B.C stressed that the students getting music education should be provided with education of three years to understand sounds and complexity of Lyra. According to Plato, singing was a kind of poem. Instrumental section was thought to be a free part in accordance with the pleasure of interpreter and Plato thought that this was highly difficult for a beginner student. However, Aristoteles put an emphasis on the emotion and experimentation in music education. He suggested this point of view as a response to Pythagoras. The terms such as educated musicians and uneducated musicians were used to separate students from one another.

\section{Place and Importance of Instruments and Choir in Education}

Some Athenians learned how to play Lyra, Kithara and Aulos in $5^{\text {th }}$ century B.C. However, these musical instruments were used to be played by professionals in public ceremonies and festivals (Henderson, 1957:81). Whether citizens in urban areas should get a music education sufficiently or only listen to it was questioned. As Aristotle claimed; could music be judged by consumer like food? Moreover, he claimed that practice was optional and thought that deterioration and corruption of practice was not necessary without citizens becoming Athenian pre-war and learning how to play musical instruments by immersing themselves in their spiritual pride. A distinction begins to emerge between urban musicians and professional musicians. The music education which was made three years by Plato reluctantly was reduced to one year. Although Aristotle and Plato disagreed to each other about many questions, they had same opinion about the importance of music in terms of 
society's education (Lukacs, 1988:121). In ethics pedagogy of these philosophers, in the turning process of human being as an individual into a good citizen, music should be used as a tool in their education and this was because of the proliferation of their internal life socially. In Hellenistic time, there were schools with only one music instructor or without any music instructor. However, learning how to sing songs in chorus was still implemented to children in the city. The music quality of citizens in urban areas declined so much that professionals had to start to join choirs in 4th century B.C as a result of failing of music quality of adult citizens. Classical Athens comedy was made for a society which could speak music, politics and war. However, it was seen that in Aristoteles's post-war presentations, the choir was decreased (Henderson, 1957:340).

There were also differences in the number of choir members. For instance; once there was a choir consisting of 7 male members in Nemea festivals, this number changed at a later period. Alcman performed her first Partheneia (Young girl song) with a choir consisting of 10 female members. Furthermore, it is known that there was a choir of 12 members in a Spartan festival celebrating Helena's marriage in $3^{\text {th }}$ century B.C... The number of the choir members for Tragedy was 12 members during the period of Aeschylus but this number was increased to 15 members at a later time. The number of the choir members for Comedian was 24 and 50 members for (kind of hymn) Dithyrambs. According to a short narrative story, a choir consisting of 35 male children set off to attend a festival in Rhegium from Messina. Herodotus stated that "Islanders in Chidos sent a choir consisting of 100 male members to Delphi at around 500 B.C. This choir was the biggest one which was heard in Classical Period. However, it is known that there was a choir consisting of 100 members in the wedding ceremony of a leading person in Macedonia at around 300 B.C (West, 1992:41). The long/big walk which was created by Ptolemais in Alexandria was designed as the biggest show in the world and 30 musicians playing Kithara were going along to choir consisting of 600 male members (A cortege comprising Gods and Kings and 200 adorned/ornamented bulls afterwards). The point that should be paid attention; large choirs (de rigueur) in Hellenistic period were in fashion. In an inscription which was dedicated to Delphoi Soteria, it is stated that there were professional singers nor more than 5 people and some comic choirs comprising 7 male members and male children members in 257/256 B.C. After a period of time little more than a century, the comedy which was composed of 4people choir was put on stage (Sifakis, 1967:71). The songs which were sung in male choirs were composed of monophonic melodies. When the musical instrument went along with human's voice, it vocalized the same sound like choir or sound one octave higher. 
In Hellenistic world of music, it is seen that musical instruments did not unite with the other ones and vocalization was made in a simple layout one by one. Aulos, Lyra and Kithara are accepted as the oldest Hellenistic musical instruments (Pic.4). Even though architectural works, sculptures and literature examples of Hellenistic culture have been protected very well even till today, there is almost no example related to the sound of music. Musicologists, who examined papyrus writings, plaster tablets and pictorial remains on the walls of cave with the workouts which were carried out since Renaissance period adapted the sound they created from the signs similar to note to Hellenistic music. Today, similar music was recorded on the compact discs that we have in acoustically-equipped studios (İlyasoğlu, 2001:5).An important part of Hellenistic music was formed with solo or choral singing. Musical instruments were played separately but mostly they went along with the human's sound. Generally, the role of musical instrument was in the back ground. The choir which had many sounds was not accompanied by a group of musicians playing musical instruments equal to generated sound, often the number of the choir members was 50 but it was still accompanied by an Aulet. This Dithyrambos which was written in accordance with Athens procedure was applied (A poem written with a irregular and emotional style like ode) (West, 1992:39).

According to a writer of Aristotle's school, when a musician sang by joining Aulos and Lyra, singing became better. The possible reason for this; the sound heard was not an additional sound to instrument's sound but a sound that could make harmony with instrument's sound. It was not good to play many musical instruments as it was making the song which is performed incomprehensible (Pic.5). Another writer stated that Aulos was more suitable for singing song than Lyra. Because, Aulos was hiding the mistakes of the singer by having harmony better whereas Lyra was showing the mistakes. The singer was able to make other things melodically as well as singing. For instance; murmuring or switching to another note from other notes in different ways. However, Hellenes did not use this kind of variation for a purpose of music. Their songs were mainly poetry texts and there was few repetition in these songs. As a result, the words were clearly heard and they did not lose in the sound of musical instrument. 


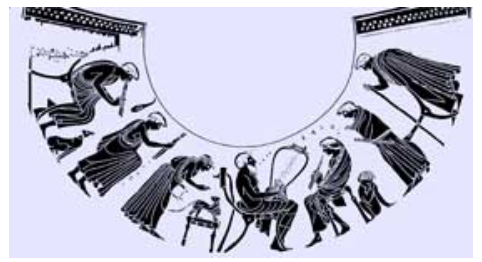

Picture 4: Music Lesson, Greek Pottery Painting British Museum 500 to 450 B.C.

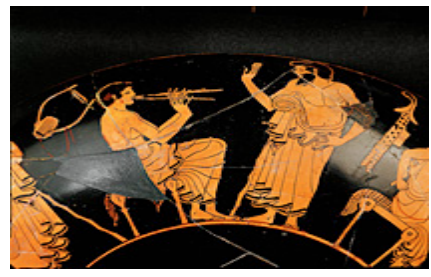

Picture 5: Music lesson, a pupil learns to play the aulos-flute. Red-figured cup, Attic, early 5th BCE

\section{Place and Importance of Music Theory in Education}

The first known poet who was interested in music theory was Lassos from Hermione. He arranged sound S (Sigma), which was most commonly used in Greek language in such a way that it was not possible to use it. The reason for this; he thought that sound S (Sigma) was inappropriate for Aulos and rude. According to Lassos, this had a meaning such as; there was another sound which was undistinguished with the presence of Aulos. There was also a technique such as; reading poetry by heart together with musical instrument as well as singing. This was named as Parakataloge. The discovery of this technique was attributed to Archilochus. Because, he is accepted as the creator of iambic poetry and rhythm (first one is short, second one is long and disyllabic rhythm type). Moreover, this technique was used in drama as well but it was not clear in which passages it was used. However, it was most probably used as; (a) two short and one long-shot measure, non-lyrical with its shape in many examples of choral starting and ending; (b) in a hexameter verse or a three measured and iambic verse in Attic dialect coming up in a lyrical text (for instance; without doric vocalization of typical tragedian song); (c) in some scenes long and short measured verses or in a verse iambic, a syllable stressed consisting of four syllables group (Gomme and Sandbach,1973:37). When compared with scenes having simple dialogue, verses went along with music were put in an order in a more tidy way. The word which could be used should be "Khanted". The one playing Aulos must have applied the same measure type but it was pretty difficult to say which melodic verse was applied (West, 1992:40). Although sound samples of Hellenic music did not reach to middle Ages, Hellenic music and its theory left deep traces in western culture for many centuries. Aristotle was in ruling power in Greece from 7 th century B.C to 2 nd century B.C. In this period, as a result of the development of Greek theatre and lyric 
poetry and increasing importance of festivals/feasts and dance, music types and musical instruments developed as well.

There were monodies played and sung by the same artist, chorus songs without any not accompanied and types of instrumental music going along with dances in Hellenic music. These forms became example for Renaissance composers at a later time. The history of seven gamut (heptatonic scala), which is regarded as the base of Western music today dates back to 3000 years B.C. These sound got their names from different parts of the country such as; Phrygia, Dorian, Lydia. The harmony of sound verses arised from certain harmony of string instruments such as Kithara and Lyra. In ancient Greece, it was believed that each mode had a special impact on human's soul. For instance; Doric verse was described as a mode suiting perfect people both in war and peace. What kind of sound does singer make? According to Sachs "There is no other place except for modern western world where natural sound is heard. For the point of view of western ear, all eastern and primitive songs are the sounds having not natural and usual characteristics (Sachs, 1940:85). In our opinion, an expression like this should be regarded as a reaction more than necessary arising from the European-based point of views of old authors (Lomax, 1968).

According to information revealed by Sachs; sounds indicated wide geographical and historical regions and specified areas that are thousands of miles in depth and width. He claimed that these there was a significant correlation between these sounds and social organization especially male dominance and women' being under pressure and not. Variables include elements related to sound such as; width, tempo, stress, singing via nose, sound amplitude, note level. These elements include sound type of singer, intonation, rhythm accuracy, pronunciation exactness (i.e. accuracy) and if there are more sounds, it also contains the harmony level of these sounds. The most commonly used praise concerning with singing in old Greek is named as Ligys or Ligyros. This was also applicable to Lyra, Aulos, Syrinx (Pan Flute), and ringing sound of cicada, wind, crying people, preachers and other elements flexible like dogs' tail, rustling and sibilant. A researcher made a definition of "ligyra" sound as refined and concentrated like cicada, grasshopper and nightingale and claimed that generally no any other foreign sound can go along with these sounds. What is more important here are not whether the sound is high or low, whether it is listened or the have a relation one another, but high tone, fineness and sensitivity of the sound? A Hellen singer did not try to make sound like a grasshopper. However, when people involved in the festival did not sing "ligyra" like nightingale, they apologized for that and their reason not singing was attendance of a similar festival the day before. What Ligys stated was quality, clarity, purity of the sound, being far from roughness and hollowness (West, 1992:42). The hoopoe of 
Aristotle praised pure sound and flowing melody of nightingale's mourning (Kaimio, 1977:202). A qualified sound was characterized with the adjectives such as; honeysweet or lily-white at the same time. These expressions stated that what is most appreciated was a pure and smooth tone. Singers used to make rehearsal before breakfast in the morning. Because, food caused the deterioration of the sound like drunkenness. While Neuron was learning how to play Kitharados, he did not skip anything done by a singer to improve and protect his sound "He put a silver sheet on his chest, He cleaned himself with enema and vomited drugs, He avoided consuming fruits causing difficulty. He intended to sing in public place even though his voice was not important but hoarse" (West, 1992:42).

The style of an educated singer was described as the opposite of all these narrated things. The notes of song were extracted in a pure way. According to Aristotle, this was the characteristic that distinguished song from speech (West, 1992:43). In speech, sound is not stopped at a certain tone. However, this is done with emotion. While singing, making constant shifting up and down is avoided, and is followed steady tone (interval) as much as possible .Melody became more accurate by making each note static and unchangeable. The sound should not pass vaguely while going up and down and it should perform notes' intervals correctly.

\section{Conclusion}

The scholars played a significant role on protecting classical language and literature with their researches. There is no research or a project carried out about music and people started to forget classical music. Plato, Aristotle and Aristoteles are the last people who teached us. Their impact on the authors who came after them were less than authority they had in two subjects such as philosophy and harmony. Aristoteles mentioned that when musicians intended to play in a classical way, they spoiled "Ethos" character by pressing wrong note (Henderson, 1957:339). Moreover, he also stated that human ear should hear three things at the same time; 1-sound, 2time and 3- letter or syllable. These were the smallest unit of music. Melody was formed when sounds came one right after the other, rhythm formed as a result of the same process of durations and poetry was made when letters came one after another. These were the subjects that should have been given in education. About the exams of music education; the Apodeikseis (exams) were made in different places like lessons. The theoretical and practical questions in the exams consisted of Mousike, Psalmos (playing Pena with Plektra), Kitharismos (playing with fingers without Plektra), Rythmographi (musical rhythm composition), Melographi (Şahin, 2013:122). 
As a result of the considerable development of music in Hellenic society, the literature, theatre and poetry of that society developed incredibly. The increasing importance of music in education brought about the emergence of the diversity in this area. As a result of a period when the concept of choir was so regarded so highly, people with a good education background started to get a better and wellequipped education. Today, this can also be regarded as the reflection of music education fundamentals.

\section{REFERENCES}

Aristoteles (1990). Politika, (çev: M.Tuncay), 3. Baskı, İstanbul: Remzi.

Dittenberger, K.F.W. (1982). Sylloge inscriptionum graecarum, 3rd edition. , Hildesheim New York.

Erhat, A. (1972). Mitoloji Sözlüğü, İstanbul: Remzi.

Gevaert, F.A. (1881). Histoire et theorie de la musique de I'antiquite, Vol.2, Ghent,Belgium.

Gomme, A.W. and Sandbach, F.H. (1973). A Commentary on Menander, London and New York: Oxford University.

Hançerlioğlu,O. (1983). Düşünce Tarihi, İstanbul: Remzi.

Henderson, I. (1957). “Ancient Greek Music”, London: Oxford University.

İlyasoğlu, E. (2001). Zaman İçinde Müzik, İstanbul: Yapı Kredi-411.

Kaimio, M. (1977). Characterization of Sound in Early Greek Literature, Helsinki: Societas

Scientiarum.

Lenkins, J. (1989). Antik Devirde Çocuk Eğitimi, (çev: H. Malay),2. Basım, İstanbul: Arkeoloji ve Sanat.

Levi, P. (1987). Eski Yunan, (çev: N. Erdilek), İstanbul: İletişim.

Lomax, A. (1968). Folk Song Style and Culture, USA: Transaction.

Lukacs, G.(1988).“Estetik III.”, (çev: A. Cemal), İstanbul: Payel.

Platon, La Republique, IV.

Sachs, C. (1940). The Wellsprings of Music, Hague, Netherlands.

Şahin, N. (2013). Antik Dönemde Anadolu'da Kadın, İzmir: Ege Üniversitesi.

Sifakis, G.M. (1967). Studies in the History of Hellenistic Drama, London.

West, M.L. (1992). Ancient Greek Music, USA: Clarendon(Oxford University). 